\title{
VEGETATIVE GROWTH, YIELD AND SOME CHEMICAL CONSTITUENTS IN LEAVES AND PODS OF COMMON BEAN AS AFFECTED BY SALICYLIC ACID AND POTASSIUM FOLIAR APPLICATION UNDER DIFFERENT IRRIGATION INTERVALS \\ Dawa, K.K;** H. M. I. Ahmed and M. H. Fekry. * \\ "Vegetable Crops and Floriculture Department, Faculty of Agriculture, Mansoura University, Egypt \\ "Vegetable Crops Seed Production and Technology Department, Horticulture Research Institute, Agricultural Research Center, Egypt
}

\begin{abstract}
Two field experiments were carried out at a Private Farm located in Salaka village, El-Mansoura, Egypt, during two successive seasons of 2011/2012. These experiments aimed to study the effect of irrigation intervals and some foliar application treatments ( salicylic acid and potassium) on common bean(Bronco cultivar) vegetative growth parameters ( plant height, number of leaves, fresh and dry weights and leaf area/plant), yield ( early yield and total yield), Chemical constituents in leaves(chlorophyll $\mathrm{a}, \mathrm{b}$ and total, N, P , K and proline content) and Chemical constituents in pods(protein, carbohydrates and sugar content). This study included 15 treatments, which were the combinations between three irrigation intervals $(10,13$ and 16 days) and five foliar application treatments including control. These treatments were arranged in a split plot in a complete randomized block design with three replicates.
\end{abstract}

The obtained results showed that the mean values of vegetative growth parameters, yield and Chemical constituents in leaves and pods of common bean plants were reduced due to increasing irrigation intervals up to 16 days during both seasons of study, while proline content increased by increasing irrigation intervals up to 16 days.

Generally, results showed that foliar application of Salicylic Acid at 15 and 30 ppm and foliar potassium at $1 \%$ and $2 \%$ improved all measured traits under both well watered and water stress conditions.

The highest significant values of the aforementioned parameters were recorded with spraying plants with Salicylic Acid at $30 \mathrm{ppm}$ and irrigation every 13 days (5 irrigations) followed with salicylic acid at $15 \mathrm{ppm}$ and foliar potassium at $1 \%$ and $2 \%$ as compared with every 10 or 16 days (4 or 6 irrigations). However, the highest mean value of leaf's proline content was obtained from the plants which irrigated every 16 days. Thus, results signify the role of SA and $\mathrm{K}$ in regulating drought response of plants and suggest that foliar salicylic acid and potassium could be used as a potential growth regulator, for improving common bean growth under water stress conditions.

Keywords: Common bean, Phaseolus vulgaris, Irrigation intervals, Salicylic acid, Potassium and proline.

\section{INTRODUCTION}

Common bean (Phaseolus vulgaris L.) is one of the most important vegetable crops grown in Egypt that occupies a great figure in local consumption and export, green bean can be grown as a summer and fall crop. According to statistics of the ministry of Agriculture and Land 
Recrimination of Egypt (2012), the total cultivated area devoted for green bean were about 62657 feddans, which produced about 270740 tons with average of 4.320 tons per feddan, respectively. About $60 \%$ of common beans produced world-wide are grown in regions subjected to water stress, making drought after diseases the second largest contributor to the yield reduction in bean (Martinez et al.2007). Thus, improving productivity of bean under such conditions is essential. Singer et al. (1996)showed that plant height, number of leaves and pods number/plant were significantly affected by water stress. Szilagyi (2003) showed that Drought stress reduced seed yield by $80 \%$, pods number per plant by $60 \%$, seeds number per pod by $26 \%$, 100 -seed weight by $13 \%$.Teranet al. (2002)reported that yield of common bean which grown in regions where water deficits during reproductive development was significantly reduced. Ucaret al. (2009) determined optimum water use of the dry bean (Phaseolus vulgaris L.) and showed that, high grain yields was obtained by meeting the full water needs of the crop. Grain yields were reduced when irrigation water was not provided during the flowering and yield formation periods. Emamet al., (2012) studied the responses of two common bean cultivars with different growth habits (Sayyad as an indeterminate and D81083 as a determinate cultivar) to drought stress. The results showed that number of pods, pod dry matter (DM) and total plant DM weights of both cultivars, were significantly reduced under drought stress. Furthermore, at 50 and $25 \%$ offull capacity, all plant pods of both cultivars were aborted. Sadeghipour and Aghaei (2012) showed that Water stress reduced number of pods per plant, number of seeds per pod, 100-seeds weight and finally seed yield of common bean. Exogenous application of SA (especially $0.5 \mathrm{mM}$ ) improved all measured traits under both well watered and water stress conditions. Also, Water stress reduced total chlorophyll content, stomatal conductance, net photosynthetic rate and proline content. Kassab and El-Zeiny (2004) investigated the effect of water stress and potassium foliar application on the productivity of faba bean plants and the results suggested that irrigation every 30 days and application of $\mathrm{K}$ with $1.5 \mathrm{l} / \mathrm{fed}$. could be recommended for maximum yield of faba bean under similar conditions. Thalooth et al.(2006) studied the effect of foliar application of zinc, potassium or magnesium on growth, yield and yield components and some chemical constituents of mungbean plants grown under water stress conditions(missing one irrigation at vegetative, flowering and pod formation growth stages). The results revealed that missing one irrigation at any of the three studied stages significantly reduced all the tested growth parameters, yield and yield components as well asphotosynthetic pigments content as compared with unstressed plants (control). However, stress at a pod formation stage produced the least yield and yield components' values. On the other hand, water stress had a stimulating effect on proline contents). Also data revealed that withholding one irrigation at any growth stage decreased the content of chl. $a+b$ and carotenoids in the leaves of mungbean plants, Data also showed that there was significantly increase in photosynthetic pigments content (chl. $a+b$ and carotenoids) under foliar application of potassium .The present studies also indicate that foliar 
application of $\mathrm{Zn}, \mathrm{K}$ or $\mathrm{Mg}$ had a positive effect on growth parameters, yield and yield components but $\mathrm{K}$ application surpassed the two other nutrients.

\section{MATERIALS AND METHODS}

Two field experiments were carried out at private farm located in Salaka village, EI- Mansoura, Egypt,(GPS, $\left.30^{\circ} 59 \mathrm{~N} 31^{\circ} 21 \mathrm{E}\right)$ during two successive summer seasons of 2011/2012. The experiments aimed to study the effect of irrigation intervals and some foliar application treatments of salicylic acid and potassium on common bean (Phaseolus vulgaris L.).

Soil analyses and layout of the Experiment

Soil analyses were done at Soil and water analysis institute, ElMansoura laboratory, Agriculture Research Center. According to Black (1965) and the results were presented in Table (1).

Dry seeds of bronco cultivar was obtained from Horticulture Research Institute, Agricultural Research Center, Egypt and sown immediately in the moderately moist soil in March $3^{\text {rd }}$ in both seasons.

Other agriculture practices were done as instructed by the Ministry of Agriculture and Soil Reclamation.

The study included 15 treatments, which were the combination between three irrigation intervals and five foliar application treatments including control as follows: Irrigation intervals (10 days, 13 days and 16 days), Foliar applications Control (tap water), Salicylic acid at 15 ppm and 30 ppm and foliar potassium at $1 \%$ and $2 \%$ as Potassium Chloride. All foliar treatments were applied three times at 30,40 and 50 days after sowing.

These treatments were arranged in a split plot in a complete randomized block design with three replicates. The main plots were used for irrigation intervals and the foliar applications were randomly arranged in the sub plots.

\section{Vegetative growth characters}

One sample of five plants of each sub-plot were randomly obtained at 60 days after sowing for measuring growth characters of common bean plants, i.e., plant height, number of leaves/plant, fresh and dry weights (leaves) and leaf area/plant according to Koller (1972).

Green pods yield harvest.

Early yield / (ton / fed.): It was determined in ton from the first green pods.

\section{Chemical constituents in leaves and green pods}

- Chlorophyll a, b and total were extracted from fresh leaves and determined according to the method of Mackinny (1941) by using spectrophotometer.

- Proline content: It was determined in leaves according to Bates et al. (1973).

- $\mathrm{N}, \mathrm{P}$ and $\mathrm{K}$ in leaves: Nitrogen and phosphorus were calorimetrically determined according the methods described in (A.O.A.C., 1992). 
Potassium was measured using the flame photometer according to Chapman and Pratt (1961).

- Protein content, Carbohydrates content and Total sugar content: It was determined in pods according to Piper (1947), Shaffer and Hartman (1921) and Smith et al. (1956).

The obtained data were subjected to statistical analysis as the technique of the split plot design to Sendcore and Corchran, (1968). The treatments means were compared using Duncan's Multiple Rang test as published by Duncan (1955).

Table (1): Soil physical and chemical properties in the two growing seasons of 2011 and 2012.

\begin{tabular}{|c|c|c|c|}
\hline \multicolumn{2}{|c|}{ Parameters } & 2011 & $Y .1 Y$ \\
\hline \multirow[b]{2}{*}{ Mechanical } & Coarse sand & Y.V & 2.9 \\
\hline & Fine sand & $r \leqslant .1$ & $r \leqslant . r$ \\
\hline \multirow{3}{*}{ Analysis (\%) } & Silt & rT.r & rT. \\
\hline & Clay & rq. $r$ & rq.r \\
\hline & Texture & Sandy clay loam & Sandy clay loam \\
\hline \multicolumn{2}{|c|}{ E.C.dS.m(1:5) } & $\cdot .9 \leq$ & 0.96 \\
\hline \multicolumn{2}{|c|}{ PH. (1:2.5) } & A.IY & 1.17 \\
\hline \multicolumn{2}{|c|}{ S.P. $\%$} & $\varepsilon r$ & $\varepsilon r$ \\
\hline \multicolumn{2}{|c|}{ O.M. \% } & $1 . V Y$ & 1.17 \\
\hline \multicolumn{2}{|c|}{$\mathrm{CaCo}_{3} \%$} & 1.97 & 1.91 \\
\hline \multirow{7}{*}{$\begin{array}{l}\text { Water soluble ions } \\
\text { meq/100g soil }\end{array}$} & $\mathrm{Ca}^{++}$ & $\cdot .9 \mathrm{~V}$ & .90 \\
\hline & $\mathrm{Mg}^{++}$ & $\cdot \leqslant V$ & $\cdot . \leqslant 9$ \\
\hline & $\mathrm{Na}^{+}$ & r.乏I & r.乏. \\
\hline & $\mathrm{K}^{+}$ & $\because \cdot 1$ & $\because \cdot 1$ \\
\hline & $\mathrm{HCO}_{3}{ }^{-}$ & $\because .74$ & .70 \\
\hline & $\mathrm{Cl}^{-}$ & $r .+1$ & $r . v$ \\
\hline & $\mathrm{SO}_{4}^{--}$ & 1.19 & I.Y. \\
\hline \multirow{3}{*}{ Available (mg/kg) } & $\mathrm{N}$ & ov.1 & 07.1 \\
\hline & $\mathrm{P}$ & 0.11 & 0.9 \\
\hline & $\mathrm{K}$ & $\pi 11$ & T10 \\
\hline
\end{tabular}

\section{RESULTS AND DISCUSSION.}

\section{Vegetative growth characters}

The results in Table(2) showed the main effect of the three irrigation intervals tested and the foliar applications of salicylic acid and foliar potassium on vegetative growth parameters (plant height, number of leaves, fresh and dry weights and leaf area/plant) of bean plants in the two growing seasons of 2011 and 2012. The results exhibited significant differences between the three irrigation intervals. The plants irrigated every 13 days recorded the highest mean value of vegetative growth parameters in comparison to irrigation every 10 days or 16 days in the two growing seasons.

With respect to the main effect of the different foliar application treatments on vegetative growth parameters, the results in Table (2) showed that application of foliar salicylic acid and potassium significantly increased the mean values of vegetative growth parameters, in relation to the control treatment in both seasons. 
J. Plant Production, Mansoura Univ., Vol. 6 (1), January, 2015

2-

61 
Concerning the interaction between irrigation intervals and foliar treatments The obtained results illustrated that the highest mean value of vegetative growth parameters was obtained from the plants that received foliar salicylic acid at $30 \mathrm{ppm}$ and irrigated every 13 days, followed by that salicylic acid at $15 \mathrm{ppm}$ and irrigated every 13 days, followed by foliar $\mathrm{K}(1 \%)$ irrigated every 13 days, followed by foliar $\mathrm{k}(2 \%)$.

The reduction of bean plant growth parameters as a result of increasing water irrigation intervals up to 16 days may be due to that water deficit is one of the major abiotic stresses which adversely affects plant growth and development. Generally, legumes are highly sensitive to water deficit stress (Labidiet al., 2009). Also water stress affected many physiological processes including photosynthesis, respiration, translocation, ion uptake, nutrient metabolisms, biosynthesis of proteins, carbohydrates and growth promoters (Sadeghipour and Aghaei, 2012).Similar studies by Emamet al. (2010) reported that plant height and leaf area were decreased significantly due to water stress. The obtained results of the study are in agreement with singer et al. (1996) on snap bean, Manjeruet al. (2007), Emamet al. (2012) and Ghanbariet al. (2013)on common bean.

\section{Green pods yield \\ Early yield ton/fed:}

Concerning the effect of irrigation intervals on early yield/fed, data presented in Table (3) indicate that bean plants which irrigated every 13 days recorded the highest mean value of early green pods per fed. On the other hand, the lowest mean value of early green pods per fed. is recorded by bean plants which irrigated every 16 days.

Also the results showed that all foliar application treatments significantly increased early green pods/fed in both growing season as compared to the control. It is evident from Table (3) that bean plants which sprayed with salicylic acid at $30 \mathrm{ppm}$ show the absolutely highest values for early green yield/ fed during the two growing seasons. Also, foliar application of $\mathrm{K}$ at the two used concentrations (i.e, $1 \%$ and $2 \%$ ) recorded higher significant early yield as compared to the control.

Data in Table (3) illustrated the effect of interaction between irrigation intervals and foliar treatments. The results reveal that foliar application of salicylic acid at $30 \mathrm{ppm}$ and irrigation every 13 days being the most effective treatment and recorded the greatest increments of early yield per fed in both seasons, followed by salicylic acid at $15 \mathrm{ppm}$, followed by foliar potassium at $1 \%$ and $2 \%$.

\section{Total yield ton/fed:}

The results presented in Table (3) indicated that there is a significant differences between the different irrigation intervals since the irrigation every 13 days recorded the highest value of yield as 6.07 and 6.33 ton/fed for the first and second seasons, respectively while irrigation every 16 days reduced the total yield to 4.84 and 5.1233 ton/fed for the first and second seasons, respectively.

Concerning the effect of foliar application either by salicylic acid or potassium, data in the same table showed that there is a markedly increment in yield over control as a result of using salicylic acid or potassium. Foliar 
application of salicylic acid at 30 ppm increased the yield by 37.25 and 38.74 $\%$ followed by salicylic acid at 15 ppm with 27.45 and $24.34 \%$ for the first and second season, respectively. While potassium at $1 \%$ came in the third rank with 16.33 and $15.41 \%$ and finally potassium at $2 \%$ with 12.2 and 9.9 $\%$ increment over control plants for the first and second seasons, respectively Table (3): Early yield and total yield of bean plants as affected by three irrigation intervals, foliar treatments and their interactions during 2011 and 2012 seasons.

\begin{tabular}{|c|c|c|c|c|c|}
\hline \multirow{2}{*}{\multicolumn{2}{|c|}{ Characters }} & \multicolumn{2}{|c|}{$\begin{array}{c}\text { Early yield } \\
\text { Ton/fed }\end{array}$} & \multicolumn{2}{|c|}{$\begin{array}{l}\text { Total yield } \\
\text { Ton/fed }\end{array}$} \\
\hline & & 2011 & 2012 & 2011 & 2012 \\
\hline \multicolumn{6}{|c|}{ Irrigation intervals } \\
\hline 10 days & & $1.75 a$ & $2.08 \mathrm{~b}$ & $5.50 \mathrm{~b}$ & $5.95 b$ \\
\hline 13 days & & $1.74 \mathrm{a}$ & $2.19 \mathrm{a}$ & $6.07 a$ & $6.33 a$ \\
\hline 16 days & & $0.95 \mathrm{~b}$ & $1.18 \mathrm{c}$ & $4.84 \mathrm{c}$ & $5.12 \mathrm{c}$ \\
\hline \multicolumn{6}{|c|}{ Foliar treatments } \\
\hline Control & & $1.16 \mathrm{e}$ & $1.31 \mathrm{e}$ & $4.59 \mathrm{e}$ & $4.93 \mathrm{e}$ \\
\hline SA (15ppm) & & $1.66 \mathrm{~b}$ & $2.03 \mathrm{~b}$ & $5.85 b$ & $6.13 b$ \\
\hline SA (30ppm) & & $1.85 \mathrm{a}$ & $2.42 \mathrm{a}$ & $6.32 a$ & $6.84 a$ \\
\hline $\mathrm{K}(1 \%)$ & & $1.40 \mathrm{c}$ & $1.74 \mathrm{c}$ & $5.43 c$ & $5.69 c$ \\
\hline $\mathrm{K}(2 \%)$ & & $1.33 \mathrm{~d}$ & $1.58 \mathrm{~d}$ & $5.15 d$ & $5.42 d$ \\
\hline \multicolumn{6}{|c|}{ Interaction } \\
\hline \multirow{5}{*}{10 days } & Control & $1.53 \mathrm{c}$ & 1.19h & $4.95 f$ & $5.39 f$ \\
\hline & SA (15ppm) & $1.99 \mathrm{~b}$ & $2.41 \mathrm{c}$ & $5.85 d$ & $6.16 \mathrm{~d}$ \\
\hline & $\mathrm{SA}(30 p p m)$ & $2.04 \mathrm{~b}$ & $2.54 \mathrm{~b}$ & $6.60 \mathrm{~b}$ & $7.31 \mathrm{a}$ \\
\hline & $\mathrm{K}(1 \%)$ & $1.64 \mathrm{c}$ & $2.00 \mathrm{e}$ & $5.07 f$ & $5.43 f$ \\
\hline & $\mathrm{K}(2 \%)$ & $1.55 \mathrm{c}$ & $1.72 \mathrm{~g}$ & $5.01 \mathrm{f}$ & $5.42 f$ \\
\hline \multirow{5}{*}{13 days } & Control & $1.16 \mathrm{~d}$ & $1.93 f$ & $4.75 \mathrm{~g}$ & $5.04 \mathrm{gh}$ \\
\hline & SA (15ppm) & $2.02 \mathrm{~b}$ & $2.50 \mathrm{~b}$ & $6.66 \mathrm{~b}$ & $6.92 b$ \\
\hline & SA(30ppm) & $2.33 \mathrm{a}$ & $2.97 a$ & $7.01 \mathrm{a}$ & $7.35 \mathrm{a}$ \\
\hline & $\mathrm{K}(1 \%)$ & $1.63 \mathrm{c}$ & $2.08 d$ & $6.22 c$ & $6.49 c$ \\
\hline & $\mathrm{K}(2 \%)$ & $1.55 \mathrm{c}$ & $1.98 \mathrm{ef}$ & $5.7 \mathrm{~d}$ & $5.91 \mathrm{e}$ \\
\hline \multirow{5}{*}{16 days } & Control & $0.77 \mathrm{f}$ & $0.80 \mathrm{j}$ & $4.05 \mathrm{~h}$ & $4.36 \mathrm{i}$ \\
\hline & SA (15ppm) & $0.98 \mathrm{e}$ & $1.18 \mathrm{~h}$ & $5.06 f$ & $5.31 \mathrm{f}$ \\
\hline & SA (30ppm) & $1.19 \mathrm{~d}$ & $1.76 \mathrm{~g}$ & $5.36 \mathrm{e}$ & $5.87 e$ \\
\hline & $\mathrm{K}(1 \%)$ & $0.94 \mathrm{e}$ & $1.14 \mathrm{~h}$ & $4.98 f$ & $5.15 \mathrm{~g}$ \\
\hline & $\mathrm{K}(2 \%)$ & $0.89 \mathrm{ef}$ & $1.04 i$ & $4.73 \mathrm{~g}$ & $4.93 \mathrm{~h}$ \\
\hline
\end{tabular}

Values within the same column followed by the same letters are not significantly differen using Duncan's Multiple Range Test at $5 \%$ level.

As regards the effect of interaction between irrigation intervals and foliar application of salicylic acid and potassium on total yield of bean plants, data in Table 4 indicate that in both seasons of study, irrigation every 13 days and spraying plants with salicylic acid at $30 \mathrm{ppm}$ was the best treatment in both seasons followed by irrigation every 13 days and spraying plants with salicylic acid at $15 \mathrm{ppm}$, followed by foliar potassium at $1 \%$ under irrigation every 13days, followed by foliar potassium at $2 \%$ under 13 days interval of irrigation, while the lowest values were recorded by extended the irrigation interval up to 16 days without any alleviation treatments.

The reduction effect of prolonging water irrigation intervals ( 16 days) on yield of common bean and its attributes may be due to many reasons reported by many researchers. The researchers stated that high moisture 
stress during the reproductive stage exposed the plant to floral abortion and resulted in low seed yield. (Barrios et al., 2005; Singh 1995 and Sponchiadoet al.,1989)they reported that water stress imposed during flowering and pod setting causes flower and pod abortion. The reproductive stage is the most sensitive stage to drought stress (Nielsen and Nelson, 1998). This phase includes flower formation (Pedroza and Muñoz, 1993), full flowering (Pimentel et al., 1999), pod formation (Castañedaet al., 2006), or grain filling (Nielsen and Nelson, 1998).

Spraying Salicylic acid at 30 and $15 \mathrm{ppm}$ showed significant increase in yield and yield. Components in both non stress and water stress conditions. Drought-related reduction in yield and yield components of plants could be ascribed to stomatal closure in response to low soil water content, which decreased the intake of $\mathrm{CO}_{2}$ and, as a result, photosynthesis decreased (Chaves, 1991.;Cornic, 2000, Flexas, et al 2004). In summary, prevailing drought reduces plant growth parameters (Table 2), leading to hampered flower production. Many studies similar to our experiment reported that water stress reduces yield and its components of common bean.

Exogenous SA application significantly improved yield and yield components of common bean in well watered and water stressed plants. Similarly Gomez, et al. (1993) found that exogenous application of SA can improve yield and yield attributes under drought stress.

Foliar application of $\mathrm{K}$ at $1 \%$ or $2 \%$ recorded higher values for all yield parameters under all irrigation treatments as compared to the untreated plants (control plants which sprayed with tap water only). The stimulator effect of potassium on the yield may be due to that potassium plays an important role in water status of plant, promoting the translocation of newly synthesized photosynthetic and mobilization of metabolites as well as promoting the synthesis of sugars and polysaccharides (Mengel and Kirkby, 1982).

Similar results were reported by Pannu and Singh (1988) on mungbean, Singer et al. (1996) on snap bean, Peterson (1989), Eliveraet al. (2003), Manjeruet al. (2007), Emamet al. (2012), Sedeghipour and Aghaei (2012) on common bean and Thaloothet al. (2006) on mungbean.

\section{Chemical constituents in leaves}

leaf's chlorophyll content

It is clear from the data in Table 4 that the mean values of chlorophyll $a, b$ and total in the leaves of bean plants were significantly affected as a result of irrigation intervals, the highest values were recorded with irrigation every 13 days followed by irrigation every 10 days. The lowest values were obtained with irrigation every 16 days in both growing seasons 2011 and 2012.

In the same table, the effect of foliar treatments showed significant differences in both seasons. Foliar treatment with salicylic acid (30 ppm) recorded the highest mean values followed by foliar treatment with salicylic acid $(15 \mathrm{ppm})$. Also, foliar potassium at (1\%) and foliar potassium at $(2 \%)$ gave higher significant values compared with (control).

In respect to the interaction effect between irrigation intervals and foliar treatments, data in Table (4) showed that the combination treatment of 
foliar salicylic acid $30 \mathrm{ppm}$ and irrigation every 13 days significantly gave the highest mean values for chl. a, chl. $b$ and total chl. in both seasons.

Leaf's proline content

Data presented in Table (4) showed the effect of the three irrigation intervals tested on leaf's proline content in both growing seasons. The results showed that the leaves of plants irrigated every 16 days had higher proline content, in the two seasons 2011 and 2012.

Regarding the leaf's content of proline, in the two growing seasons of 2011 and 2012 due to the application of different foliar treatments are shown in Table (4),

Table (4):Leaf's chlorophyll content and proline of common bean plants as affected by three irrigation intervals, foliar treatments and their interactions during 2011 and 2012 seasons.

\begin{tabular}{|c|c|c|c|c|c|c|c|c|c|}
\hline \multirow{2}{*}{\multicolumn{2}{|c|}{ Characters }} & \multicolumn{2}{|c|}{$\begin{array}{c}\text { Chl. a } \\
\text { Mg g-1fw }\end{array}$} & \multicolumn{2}{|c|}{$\begin{array}{c}\text { Chl. b } \\
\text { mg g-1fw }\end{array}$} & \multicolumn{2}{|c|}{$\begin{array}{l}\text { Chl. } a+b \\
\text { mg g-1fw }\end{array}$} & \multicolumn{2}{|c|}{$\begin{array}{c}\text { Proline } \\
\mu \text { mol g-1fw }\end{array}$} \\
\hline & & 2011 & 2012 & 2011 & 2012 & 2011 & 2012 & 2011 & 2012 \\
\hline \multicolumn{10}{|c|}{ Irrigation intervals } \\
\hline \multicolumn{2}{|c|}{10 days } & $0.550 \mathrm{~b}$ & $0.599 \mathrm{~b}$ & $0.384 \mathrm{~b}$ & $0.431 \mathrm{~b}$ & $0.934 \mathrm{~b}$ & $1.030 \mathrm{~b}$ & 7.132 & $6.300 \mathrm{c}$ \\
\hline \multicolumn{2}{|c|}{13 days } & $0.577 \mathrm{a}$ & $0.624 \mathrm{a}$ & $0.402 \mathrm{a}$ & $0.461 \mathrm{a}$ & $777 \mathrm{a}$ & $85 \mathrm{a}$ & 7.452 & $6.783 \mathrm{~b}$ \\
\hline \multicolumn{2}{|c|}{16 days } & $0.524 \mathrm{c}$ & $0.571 \mathrm{c}$ & $0.365 \mathrm{c}$ & $0.406 \mathrm{c}$ & $0.892 \mathrm{c}$ & & 7.668 & $7.234 \mathrm{a}$ \\
\hline \multicolumn{10}{|c|}{ Foliar treatments } \\
\hline \multicolumn{2}{|c|}{ Control } & $0.531 \mathrm{e}$ & $0.561 \mathrm{e}$ & $0.370 \mathrm{e}$ & $0.402 \mathrm{e}$ & $0.901 \mathrm{e}$ & $0.964 \mathrm{e}$ & 7.036 & 6.440 \\
\hline \multicolumn{2}{|c|}{ SA $15 \mathrm{ppm}$} & $0.560 \mathrm{~b}$ & $0.616 \mathrm{~b}$ & $0.391 \mathrm{~b}$ & $0.447 \mathrm{~b}$ & $0.951 \mathrm{~b}$ & $63 \mathrm{~b}$ & 7.598 & 6.938 \\
\hline \multicolumn{2}{|c|}{ SA $30 \mathrm{ppm}$} & $0.568 \mathrm{a}$ & $0.634 \mathrm{a}$ & $0.396 \mathrm{a}$ & $0.462 \mathrm{a}$ & $0.964 \mathrm{a}$ & $97 \mathrm{a}$ & 7.778 & 7.048 \\
\hline \multicolumn{2}{|c|}{ K 1\% } & $0.552 \mathrm{c}$ & $0.599 \mathrm{c}$ & $0.384 \mathrm{c}$ & $0.434 \mathrm{c}$ & $0.934 \mathrm{c}$ & $1.034 \mathrm{c}$ & 7.451 & 6.788 \\
\hline \multicolumn{2}{|l|}{ K 2\% } & $0.541 \mathrm{~d}$ & $0.580 \mathrm{~d}$ & $0.376 \mathrm{~d}$ & $0.418 \mathrm{~d}$ & $0.921 \mathrm{~d}$ & $38 \mathrm{~d}$ & 7.221 & $6.647 \mathrm{~d}$ \\
\hline \multicolumn{10}{|c|}{ Interaction } \\
\hline \multirow{5}{*}{$\begin{array}{l}10 \\
\text { days }\end{array}$} & & $0.530 \mathrm{fg}$ & $0.572 \mathrm{~h}$ & 0.369hi & $0.402 \mathrm{gh}$ & 0.899hi & $0.957 \mathrm{i}$ & 6.563 & $5.940 \mathrm{k}$ \\
\hline & SA 15 & $0.561 \mathrm{bc}$ & $0.614 \mathrm{~d}$ & $0.392 \mathrm{~cd}$ & $0.445 \mathrm{~cd}$ & $0.953 \mathrm{e}$ & 1.059de & 7.380 & $6.476 \mathrm{~h}$ \\
\hline & SA 30 & $0.570 \mathrm{~b}$ & $0.625 \mathrm{c}$ & $0.396 \mathrm{c}$ & $0.459 \mathrm{bc}$ & $0.968 \mathrm{~cd}$ & $1.084 \mathrm{c}$ & $7.693 \mathrm{~cd}$ & 6.590 \\
\hline & K 1\% & $0.550 \mathrm{~d}$ & $0.600 \mathrm{e}$ & 0.384 ef & $0.432 \mathrm{de}$ & $0.935 \mathrm{f}$ & $1.032 \mathrm{f}$ & $7.190 \quad \mathrm{i}$ & $6.300 \mathrm{i}$ \\
\hline & $\mathrm{K} 2 \%$ & $0.538 \mathrm{ef}$ & $0.584 \mathrm{~g}$ & $0.378 \mathrm{fg}$ & $0.418 \mathrm{efg}$ & $0.916 \mathrm{~g}$ & $1.002 \mathrm{~h}$ & 6.833 & $6.196 \mathrm{j}$ \\
\hline \multirow{5}{*}{$\begin{array}{l}13 \\
\text { days }\end{array}$} & Cont & $0.560 \mathrm{c}$ & $0.592 \mathrm{f}$ & & & $0.947 \mathrm{e}$ & $27 \mathrm{f}$ & 7.123 & $6.460 \mathrm{~h}$ \\
\hline & SA 15 & $0.583 \mathrm{a}$ & $0.640 \mathrm{~b}$ & $0.409 a b$ & $0.474 \mathrm{ab}$ & $0.992 \mathrm{~b}$ & $14 \mathrm{~b}$ & $7.616 \mathrm{~d}$ & $6.976 \mathrm{e}$ \\
\hline & SA 30 & $0.591 \mathrm{a}$ & $0.654 \mathrm{a}$ & $0.415 \mathrm{a}$ & $0.485 \mathrm{a}$ & $1.006 \mathrm{a}$ & $1.139 \mathrm{a}$ & 7.746 bc & 7.083 \\
\hline & K 1\% & $0.581 \mathrm{a}$ & $0.627 \mathrm{c}$ & $0.405 \mathrm{~b}$ & $0.463 \mathrm{bc}$ & $0.977 \mathrm{c}$ & $1.090 \mathrm{c}$ & 7.483 ef & 6.783 \\
\hline & K 2\% & $0.571 \mathrm{~b}$ & $0.608 \mathrm{~d}$ & $0.393 \mathrm{~cd}$ & $0.448 \mathrm{~cd}$ & $0.964 \mathrm{~d}$ & $1.056 \mathrm{e}$ & $7.290 \mathrm{~h}$ & 6.613 \\
\hline \multirow{5}{*}{$\begin{array}{l}16 \\
\text { days }\end{array}$} & Control & \begin{tabular}{|l|}
$0.503 \mathrm{i}$ \\
\end{tabular} & $0.520 \mathrm{j}$ & $0.354 \mathrm{k}$ & $0.369 \mathrm{i}$ & $0.857 \mathrm{k}$ & $0.890 \mathrm{k}$ & $7.423 \mathrm{fg}$ & $6.920 \mathrm{e}$ \\
\hline & SA $15 \mathrm{ppm}$ & $0.535 \mathrm{ef}$ & 0.596 ef & $0.374 \mathrm{gh}$ & 0.423 ef & $0.910 \mathrm{gh}$ & $1.017 \mathrm{~g}$ & $7.800 \mathrm{~b}$ & $7.363 \mathrm{~b}$ \\
\hline & SA $30 \mathrm{ppm}$ & \begin{tabular}{|l|}
$0.542 \mathrm{de}$ \\
\end{tabular} & $0.623 \mathrm{c}$ & $0.375 \mathrm{gh}$ & $0.444 \mathrm{~cd}$ & $0.918 \mathrm{~g}$ & $1.068 \mathrm{~d}$ & \begin{tabular}{|l}
$7.896 \mathrm{a}$ \\
\end{tabular} & $7.473 \mathrm{a}$ \\
\hline & K 1\% & $0.524 \mathrm{gh}$ & $0.571 \mathrm{~h}$ & $0.363 \mathrm{ij}$ & $0.409 \mathrm{fg}$ & $0.891 \mathrm{ij}$ & $0.980 \mathrm{i}$ & $7.680 \mathrm{~cd}$ & $7.283 \mathrm{c}$ \\
\hline & K 2\% & $0.515 \mathrm{~h}$ & $0.546 \mathrm{i}$ & $0.358 \mathrm{jk}$ & $0.389 \mathrm{~h}$ & $0.884 \mathrm{j}$ & $0.935 \mathrm{j}$ & $7.540 \mathrm{e}$ & $7.133 \mathrm{~d}$ \\
\hline
\end{tabular}

Values within the same column followed by the same letters are not significantly different using Duncan's Multiple Range Test at $5 \%$ level.

The data clearly pointed out that using foliar treatment increased significantly leavesproline content in both seasons comparing with control. The obtained values cleared that treatment with foliar salicylic acid at $30 \mathrm{ppm}$ gave the highest significant proline content compared with the other treatments in both seasons.

Data in Table (4) showed the effect of various treatment combinations of irrigation intervals and foliar treatments ofproline content in both seasons. 
The combination treatment of foliar salicylic acid at $30 \mathrm{ppm}$ and irrigation every 16 days, recorded the highest mean values of proline content in the both seasons.

\section{Mineral contents of leaves}

The results concerning the general effects of the two studied factors as well as their interactions on leaf mineral contents are listed in Table (5), in the two growing seasons. The results of Table (5) indicated that plants irrigated every 13 days had higher leaf $\mathrm{N}, \mathrm{P}$ and $\mathrm{K}$ percentages, in both growing seasons.

Regarding the influences of the applied different foliar treatments on leaf mineral contents, the data presented in Table (5) showed clearly that the application of all foliar treatments, generally, caused higher corresponding significant increase on leaf's $\mathrm{N}, \mathrm{P}$ and $\mathrm{K}$ percentages, relative to the control, in both seasons.

The interaction between irrigation intervals and foliar treatments had a significant effect on leaf's $\mathrm{N}, \mathrm{P}$ and $\mathrm{K}$ percentages, in both growing seasons. The highest mean values for leaf's $\mathrm{N}, \mathrm{P}$ and $\mathrm{K}$ contents were obtained when plants were irrigated every 13 days and plants received foliar salicylic acid at $30 \mathrm{ppm}$ in both growing seasons.

Table (5):Leaf' $s$ contents $N, P$ and $K$ percentage of common bean leaves as affected by three irrigation intervals, foliar treatments and their interactions during 2011 and 2012 seasons.

\begin{tabular}{|c|c|c|c|c|c|c|c|}
\hline \multirow{2}{*}{ treatments } & \multirow{2}{*}{ Characters } & \multicolumn{2}{|c|}{$\mathbf{N} \%$} & \multicolumn{2}{|c|}{$\mathbf{P} \%$} & \multicolumn{2}{|c|}{ K \% } \\
\hline & & 2011 & 2012 & 2011 & 2012 & 2011 & 2012 \\
\hline \multicolumn{8}{|c|}{ Irrigation intervals } \\
\hline 10 days & & $3.412 \mathrm{~b}$ & $3.608 \mathrm{~b}$ & $0.396 \mathrm{~b}$ & $0.403 \mathrm{~b}$ & $2.144 \mathrm{~b}$ & $2.339 \mathrm{~b}$ \\
\hline 13 days & & $3.584 \mathrm{a}$ & $3.866 \mathrm{a}$ & $0.428 \mathrm{a}$ & $0.429 \mathrm{a}$ & $2.240 \mathrm{a}$ & $2.524 \mathrm{a}$ \\
\hline 16 days & & $3.167 \mathrm{c}$ & $3.308 \mathrm{c}$ & $0.366 \mathrm{c}$ & $0.378 \mathrm{c}$ & $1.987 \mathrm{c}$ & $2.134 c$ \\
\hline \multicolumn{8}{|c|}{ Foliar treatments } \\
\hline Control & & $3.166 \mathrm{e}$ & $3.488 \mathrm{e}$ & $0.384 \mathrm{e}$ & $0.372 \mathrm{e}$ & $1.986 \mathrm{~d}$ & $2.265 d$ \\
\hline SA 15ppm & & $3.482 \mathrm{~b}$ & $3.645 \mathrm{~b}$ & $0.402 \mathrm{~b}$ & $0.413 \mathrm{~b}$ & $2.177 \mathrm{~b}$ & $2.365 \mathrm{~b}$ \\
\hline SA 30ppm & & $3.535 \mathrm{a}$ & $3.703 \mathrm{a}$ & $0.409 \mathrm{a}$ & $0.421 \mathrm{a}$ & $2.232 \mathrm{a}$ & $2.414 \mathrm{a}$ \\
\hline K 1\% & & $3.422 \mathrm{c}$ & $3.604 \mathrm{c}$ & $0.397 \mathrm{c}$ & $0.408 \mathrm{c}$ & $2.125 \mathrm{C}$ & $2.330 \mathrm{c}$ \\
\hline $\mathrm{K} 2 \%$ & & $3.334 \mathrm{~d}$ & $3.528 \mathrm{~d}$ & $0.392 \mathrm{~d}$ & $0.402 \mathrm{~d}$ & $2.096 \mathrm{C}$ & $2.286 \mathrm{C}$ \\
\hline \multicolumn{8}{|c|}{ Interaction } \\
\hline \multirow{5}{*}{10 days } & Control & $3.233 \mathrm{ef}$ & $3.476 \mathrm{~g}$ & $0.383 \mathrm{~h}$ & $0.374 \mathrm{ghi}$ & $1.986 \mathrm{ghi}$ & $2.273 \mathrm{f}$ \\
\hline & SA 15ppm & $3.513 \mathrm{c}$ & $3.653 \mathrm{e}$ & $0.403 \mathrm{f}$ & $0.410 \mathrm{e}$ & $2.203 \mathrm{~cd}$ & $2.363 \mathrm{~d}$ \\
\hline & SA 30ppm & $3.530 \mathrm{c}$ & $3.726 \mathrm{~d}$ & $0.410 \mathrm{e}$ & $0.417 \mathrm{~d}$ & $2.286 \mathrm{ab}$ & $2.446 \mathrm{c}$ \\
\hline & & $3.420 \mathrm{~d}$ & $3.640 \mathrm{e}$ & $0.395 \mathrm{~g}$ & $0.408 \mathrm{e}$ & $2.150 \mathrm{de}$ & $2.330 \mathrm{de}$ \\
\hline & $\mathrm{K} 2 \%$ & $3.366 \mathrm{~d}$ & $3.543 \mathrm{f}$ & $0.391 \mathrm{~g}$ & $0.405 \mathrm{e}$ & $2.093 \mathrm{ef}$ & $2.283 \mathrm{ef}$ \\
\hline \multirow{5}{*}{13 days } & Control & $3.166 \mathrm{gh}$ & $3.763 \mathrm{~d}$ & $0.420 \mathrm{~d}$ & $0.372 \mathrm{hi}$ & $2.060 \mathrm{fg}$ & $2.446 \mathrm{c}$ \\
\hline & SA 15ppm & $3.760 a b$ & $3.930 \mathrm{a}$ & $0.431 \mathrm{~b}$ & $0.452 \mathrm{a}$ & $2.296 \mathrm{ab}$ & $2.570 \mathrm{ab}$ \\
\hline & SA 30ppm & $3.793 \mathrm{a}$ & $3.963 \mathrm{a}$ & $0.435 \mathrm{a}$ & $0.457 \mathrm{a}$ & $2.356 \mathrm{a}$ & $2.603 \mathrm{a}$ \\
\hline & K 1\% & $3.703 \mathrm{~b}$ & $3.866 \mathrm{~b}$ & $0.428 \mathrm{bc}$ & $0.438 \mathrm{~b}$ & $2.243 \mathrm{bc}$ & $2.536 \mathrm{~b}$ \\
\hline & $\mathrm{K} 2 \%$ & $3.500 \mathrm{c}$ & $3.810 \mathrm{c}$ & $0.425 \mathrm{c}$ & $0.425 \mathrm{c}$ & $2.243 \mathrm{bc}$ & $2.463 \mathrm{c}$ \\
\hline \multirow{5}{*}{16 days } & Control & $3.100 \mathrm{~h}$ & $3.226 \mathrm{k}$ & $\begin{array}{ll}0.351 \quad \mathrm{I} \\
\end{array}$ & $0.370 \mathrm{i}$ & $1.913 \mathrm{i}$ & $2.076 \mathrm{i}$ \\
\hline & SA 15ppm & $3.173 \mathrm{fg}$ & $3.353 i$ & $0.372 \mathrm{i}$ & $0.379 \mathrm{~g}$ & $2.033 \mathrm{fgh}$ & $2.163 \mathrm{gh}$ \\
\hline & SA 30ppm & $3.283 \mathrm{e}$ & $3.420 \mathrm{~h}$ & $0.382 \mathrm{~h}$ & $0.389 \mathrm{f}$ & $2.053 \mathrm{fgh}$ & $2.193 \mathrm{~g}$ \\
\hline & K 1\% & 3.143gh & $3.306 \mathrm{j}$ & $0.367 \mathrm{j}$ & $0.377 \mathrm{gh}$ & $1.983 \mathrm{hi}$ & $2.123 \mathrm{hi}$ \\
\hline & K 2\% & $3.136 \mathrm{gh}$ & $3.233 \mathrm{k}$ & $0.359 \mathrm{k}$ & $0.376 \mathrm{ghi}$ & $1.953 \mathrm{i}$ & $2.113 \mathrm{hi}$ \\
\hline
\end{tabular}

Values within the same column followed by the same letters are not significantly different using Duncan's Multiple Range Test at $5 \%$ level. 
Photosynthetic efficiency depends to large extent on quantity and quality of photosynthetic pigments such as chlorophyll a and chlorophyll $b$ which play an important role in photochemical reactions of photosynthesis (Taiz and Zeiger, 2002). Water stress can inhibit photosynthesis of plants by affecting chlorophyll components, causing changes in chlorophyll content, and damaging the photosynthetic apparatus in plants (IturbeOrmaetxeet al. 1998). The current study showed significant differences among water irrigation interval treatments for chlorophyll $a$, chlorophyll $b$ and total chlorophyll contents especially after being subjected to water stress. There was a general decrease in the leaf chlorophyll content in plants subjected to water stress.

The decrease in chlorophyll in the study was more in high water stress condition than in the low water stress and normally irrigated condition (Table 4). The highest decrease in total chlorophyll content was obtained from irrigation every16 days. Many workers found that chlorophyll content decreased with water stress indicating that photosynthetic pigments are sensitive to water stress conditions. A reduction in chlorophyll content was also reported in drought stressed common bean (Santos et al. 2009).

The obtained results (Table 4 ) showed that application of salicylic acid at 15 and $30 \mathrm{ppm}$ have revealed appositive effect on photosynthesis pigments ( chlorophyll a, b and total chlorophyll) of common bean in both non stress and water stress conditions.

Similar results were reported by Sedeghipour and Aghaei (2012) andMafakheri1 et al. (2010)

Under vegetative stage, drought stress increased proline content about tenfold, this increasing roles as an osmotic compatible and adjust osmotic potential which resulted in drought stress avoidance in chickpea. Proline accumulation is believed to play adaptive roles in plant stress tolerance (Verbruggen and Hermans 2008). Accumulation of proline has been advocated as a parameter of selection for stress tolerance (Yancyet al. 1982. Jaleelet al. 2007).

\section{Chemical constituents of green pods}

\section{Protein, Carbohydrates and Total sugar contents}

Data given in Table (6) showed the effect of the tested irrigation intervals on protein, carbohydrates and total sugar content of green pods, in two growing seasons of 2011 and 2012. The results of the comparison among the protein content mean values, of three tested irrigation intervals illustrated significant differences of this character, in both growing seasons, since the highest values were recorded with irrigated plants every 13 days.

Also data in Table (6) indicated that using foliar salicylic acid $30 \mathrm{ppm}$ was superior to other foliar treatments in protein, carbohydrates and total sugar content, in both seasons 2011 and 2012. There were significant differences between the foliar treatments in both seasons.

The interaction effect between irrigation intervals and foliar treatments reflected significant differences on protein, carbohydrates and total sugar content in both seasons. The combination treatment of foliar 
salicylic acid $30 \mathrm{ppm}$ and irrigation every 13 days, recorded the highest mean values of protein content in the both seasons.

The results in this study showed that foliar applications of Salicylic acid and Potassium had appositive effect on quality characters of common bean (i.e. protein content, carbohydrate content and sugar content). This positive effect may be due to the application of Salicylic acid and Potassium improve chlorophyll content, stomatal conductance and finally net photosynthetic rate of common bean in both non stress and stress conditions as mentioned by Sedeghipour and Aghaei(2012).

Also, Sufficient $\mathrm{K}$ induces solute accumulation, thus lowering osmotic potential and helping to maintain plant cell turgor under osmotic stress.

The result is agreement with Azzaet al. (2007) who showed that irrigation intervals treatments have a depressing effect on sugar content. And spraying potassium at $50 \mathrm{ppm}$ increased sugar content as compared with the untreated one

Table (6): Protein, carbohydrates and sugar of common bean plants as affected by three irrigation intervals, foliar treatments and their interactions during 2011 and 2012 seasons.

\begin{tabular}{|c|c|c|c|c|c|c|c|}
\hline \multirow{2}{*}{\multicolumn{2}{|c|}{ treatments }} & \multicolumn{2}{|c|}{$\begin{array}{c}\text { Protein } \\
\%\end{array}$} & \multicolumn{2}{|c|}{$\begin{array}{c}\text { Carbohydrates } \\
\%\end{array}$} & \multicolumn{2}{|c|}{$\begin{array}{c}\text { Sugar } \\
\%\end{array}$} \\
\hline & & 2011 & 2012 & 2011 & 2012 & 2011 & 2012 \\
\hline \multicolumn{8}{|c|}{ Irrigation intervals } \\
\hline \multicolumn{2}{|l|}{10 days } & $13.177 \mathrm{~b}$ & $13.810 \mathrm{~b}$ & $18.149 \mathrm{~b}$ & $18.468 \mathrm{~b}$ & $4.828 \mathrm{~b}$ & $5.408 \mathrm{~b}$ \\
\hline \multicolumn{2}{|l|}{13 days } & $13.849 a$ & $14.855 a$ & $19.256 a$ & $19.530 a$ & $5.040 \mathrm{a}$ & $5.686 \mathrm{a}$ \\
\hline \multicolumn{2}{|l|}{16 days } & $12.318 \mathrm{c}$ & $12.707 c$ & $16.678 \mathrm{c}$ & $17.772 \mathrm{c}$ & $4.714 \mathrm{c}$ & $5.162 \mathrm{c}$ \\
\hline \multicolumn{8}{|c|}{ Foliar treatments } \\
\hline \multicolumn{2}{|c|}{ Control } & $12.261 \mathrm{e}$ & $13.404 \mathrm{e}$ & $17.706 \mathrm{e}$ & $17.502 \mathrm{e}$ & $4.705 \mathrm{~d}$ & $5.326 \mathrm{e}$ \\
\hline \multicolumn{2}{|c|}{ SA $15 \mathrm{ppm}$} & $13.586 \mathrm{~b}$ & $13.978 b$ & $18.326 \mathrm{~b}$ & $18.994 \mathrm{~b}$ & $4.915 \mathrm{~b}$ & $5.462 \mathrm{~b}$ \\
\hline \multicolumn{2}{|c|}{ SA $30 \mathrm{ppm}$} & $13.772 a$ & $14.206 a$ & $18.530 a$ & $19.213 a$ & $4.981 \mathrm{a}$ & $5.520 \mathrm{a}$ \\
\hline \multicolumn{2}{|c|}{ K 1\% } & $13.085 \mathrm{c}$ & $13.778 \mathrm{c}$ & $18.120 \mathrm{c}$ & $18.763 \mathrm{c}$ & $4.880 \mathrm{~b}$ & $5.420 \mathrm{c}$ \\
\hline \multicolumn{2}{|l|}{ K 2\% } & $12.868 d$ & $13.586 \mathrm{~d}$ & $17.955 d$ & $18.477 d$ & $4.822 \mathrm{c}$ & $5.367 \mathrm{~d}$ \\
\hline \multicolumn{8}{|c|}{ Interaction } \\
\hline \multirow{5}{*}{10 days } & Control & $12.166 \mid$ & $13.433 \mathrm{i}$ & $17.690 \mathrm{j}$ & $17.420 \quad \mid$ & 4.693gh & $5.280 \mathrm{i}$ \\
\hline & SA 15 ppm & $13.633 \mathrm{~d}$ & $13.990 \mathrm{f}$ & $18.396 \mathrm{~g}$ & $18.886 \mathrm{f}$ & $4.896 \mathrm{~d}$ & $5.473 \mathrm{f}$ \\
\hline & SA 30 ppm & $13.740 \mathrm{c}$ & $14.183 \mathrm{e}$ & $18.616 \mathrm{f}$ & $19.113 \mathrm{e}$ & $4.933 \mathrm{~cd}$ & $5.553 \mathrm{e}$ \\
\hline & K 1\% & $13.250 \mathrm{f}$ & $13.843 \mathrm{~g}$ & $18.113 \mathrm{~h}$ & $18.653 \mathrm{~g}$ & $4.816 \mathrm{e}$ & $5.403 \mathrm{~g}$ \\
\hline & K 2\% & $13.096 \mathrm{~g}$ & $13.603 \mathrm{~h}$ & $17.930 \mathrm{i}$ & $18.266 \mathrm{~h}$ & $4.800 \mathrm{e}$ & $5.333 \mathrm{~h}$ \\
\hline \multirow{5}{*}{13 days } & Control & $12.633 \mathrm{i}$ & $14.376 d$ & $18.920 \mathrm{e}$ & $17.923 \mathrm{j}$ & 4.776 ef & $5.606 \mathrm{~d}$ \\
\hline & SA 15 ppm & $14.633 \mathrm{~b}$ & $15.193 \mathrm{a}$ & $19.373 \mathrm{~b}$ & $20.073 \mathrm{~b}$ & $5.123 \mathrm{~b}$ & $5.726 \mathrm{~b}$ \\
\hline & SA 30 ppm & $14.803 \mathrm{a}$ & $15.270 \mathrm{a}$ & $19.503 \mathrm{a}$ & 20.346 a & $5.220 \mathrm{a}$ & $5.783 \mathrm{a}$ \\
\hline & $\mathrm{K} 1 \%$ & $13.740 \mathrm{c}$ & $14.860 \mathrm{~b}$ & $19.296 \mathrm{c}$ & $19.786 \mathrm{c}$ & $5.096 \mathrm{~b}$ & $5.680 \mathrm{c}$ \\
\hline & K 2\% & $13.436 \mathrm{e}$ & $14.576 \mathrm{c}$ & $19.186 \mathrm{~d}$ & $19.523 \mathrm{~d}$ & $4.983 \mathrm{c}$ & $5.636 \mathrm{~d}$ \\
\hline \multirow{5}{*}{16 days } & Control & $11.983 n$ & $12.403 \mathrm{~m}$ & 16.5100 & $17.163 \mathrm{~m}$ & $4.646 \mathrm{~h}$ & 5.093 I \\
\hline & SA 15 ppm & $12.493 \mathrm{j}$ & $12.753 \mathrm{k}$ & $17.210 \quad$ I & $18.023 \mathrm{i}$ & $4.726 f g$ & 5.186hk \\
\hline & SA 30 ppm & $12.773 \mathrm{~h}$ & $13.166 \mathrm{j}$ & $17.470 \mathrm{k}$ & $18.180 \mathrm{~h}$ & 4.790ef & $5.223 \mathrm{j}$ \\
\hline & $\mathrm{K} 1 \%$ & $12.266 \mathrm{k}$ & $12.633 \mathrm{kl}$ & $16.950 \mathrm{~m}$ & $17.850 \mathrm{j}$ & $4.726 f g$ & $5.176 \mathrm{k}$ \\
\hline & $\mathrm{K} 2 \%$ & $12.073 \mathrm{~m}$ & $12.580 \mid$ & $16.750 n$ & $17.643 \mathrm{k}$ & 4.683gh & 5.133 I \\
\hline
\end{tabular}

Values within the same column followed by the same letters are not significantly different using Duncan's Multiple Range Test at $5 \%$ level. 


\section{REFERENCES}

Acosta-Gallegos, J.A.; and J. Kohashi-Shibata(1989).Effect of water stress on growth and yield of indeterminate dry bean (Phaesolus vulgaris) cultivars. Field Crop Res. 20:81-90.

AzzaA.M.Mazher, A.A.;Yassen and S. M. Zaghloul(2007). influence of foliar application of potassium on growth and chemical components of Bauhinia varigata seedlings under different irrigation intervals. World journal of agriculture sciences. 3(1):23-31.

Barrios, A.; Hoogenboom, and G., Nesmith (2005).Drought stress and the distribution of vegetative and reproductive traits of a bean cultivar. Sci.agric.(Piracicaba, Braz.) 62(1), 18-22

Boutraa, T. and F.E. Sanders( 2001). Influence of water stress on grain yield and vegetative growth of two cultivars of bean (Phaseolus vulgaris, L.). J. Agron. Crop. Sci., 187: 251-257.

Chaves, M. (1991). Effects of water deficits on carbon assimilation. J. Exp. Bot. 42:1-16.

Dornbos D.L; Mullen R.E and R.M.Shibles (1989). Drought stress effects during seedfill on soybean seed germination and vigor. Crop Sci. 29: 476-480.

Elvira Gonzalez de Mej, VioletaMart'ınez-Resendiz.; Eduardo Castan oTostado and Guadalupe Loarca-Pin (2003).Effect of drought on polyamine metabolism, yield, protein content and in vitro protein digestibility in tepary ( Phaseolusacutifolius) and common (Phaseolus vulgaris) bean seeds J SciFoodAgric 83:1022-1030.

Emam Y., A. Shekoofa.; F. Salehi and A.H. Jalali(2010). Water Stress Effects on Two Common Bean Cultivars with Contrasting Growth Habits. American-Eurasian J. Agric. \& Environ. Sci., 9 (5): 495-499.

Emam. Y., A. Shekoofa.; F. Salehi, A. H. Jalali and M. Pessarakli(2012). Drought stress effects on two common bean cultivars with contrasting growth habits. Archives of Agronomy and Soil Science, 58 (5): pp527-534.

Flexas, J. M.;Ribas-Carbó; J. Bota, J. Galmés, M. Henkle and S. Medrano (2006).

Decreased Rubisco activity during water stress is not induced MartínezCañellas and $\mathrm{H}$. by decreased relative water content but related to conditions of low stomatal conductance and chloroplast $\mathrm{CO} 2$ concentration. New Phytol. 172:73-82.

Ghashghaie J,M .;Duranceau ,F.W Badeck, G. Cornic, Adeline M-T and E.Deleens(2001). d13C of CO2 respired in the dark in relation to d13C of leaf metabolites: comparison between Nicotianasylvestris and Helianthus annuus under drought. Plant Cell Environ 24: 505515.

Ghanbari A.K., S.H.; Mousavi, A.M. Gorjiand R.A.Idupulapati (2013). Effects Of Water Stress On Leaves And Seeds Of Bean (Phaseolus Vulgaris L.) Turkish Journal of Field Crops, 18(1), 73-77 
Gomez, L., L.; Blanca and C.S. Antonio(1993).Evidence of the beneficent action of the acetyl salicylic acid on wheat genotypes yield under restricted irrigation. In: Proc. scientific meeting on Forestry, Livestock and Agriculture Mexico., p: 112.

Jaleel.C.A.; R.Gopi, B.Sankar, P.Manivannan, A. Kishorekumar, R. Sridharan and R.Panneerselvam(2007). Studies on germination, seedling vigour, lipid peroxidation and proline metabolism in Catharan thusroseus seedlings under salt stress, South Afr. J. Bot. 73: 190-195.

Kassab, O.M. and H.; A.El-Zeiny (2004). Effect of water stress and potassium foliar application on the productivity of faba bean plants. Annals of Agric.SC.,Moshtohor. Vol.42(4):1517-1523.

Kpyoarissis.,A.Y.; Petropoulou and Y. Manetas(1995). Summer survival of leaves in asoft-leaved shrub (Phlomisfruticosa L., Labiatae) under Mediterranean field conditions: avoidance of photoinhibitory damage through decreased chlorophyll contents. Journal of Experimental Botany 46: 1825-1831.

IturbeOrmaetxe, I.; P. R. Escuredo, C. Arrese-Igor and M. Becana.(1988).

Oxidative damage in pea plants exposed to water deficit or paraquat. Plant Physiol., 116: 173- 181.

Labidi, N. H.;Mahmoudi, M. Dorsaf, I.Slama I and C. Abdelly(2009).Assessment of intervarietal differences in drought tolerance in chickpea using both nodule and plant traits as indicators. Journal of Plant Breeding and Crop Science 1: 80-86.

Lopez, F.B.;C. Johansen, and Y.S. Chauhan(1996). Effect of timing of drought stress on phenology, yield and yield components of a shortduration pigeon pea. Journal of Agronomy \& Crop Science, v.177, p.311-320.

Mafakheri A. A.; Siosemardeh, B. Bahramnejad, P.C. Struik and Y. Sohrabi (2010). Effect of drought stress on yield, proline and chlorophyll contents in three chickpea cultivars. AJCS 4(8):580-585

Martinez, J.P.;H.S.ilva, J.F.Ledent and M.Pinto (2007).Effect of drought stress on

the osmotic adjustment, cell wall elasticity and cell volume of six cultivars of common beans (Phaseolus vulgaris L.), European Journal of Agronomy (26):30-38.

Nielsen ,D .C and N.O. Nelson (1998). Black bean sensitivity to water stress at various growth stages. Crop Sci. 38: 422-427.

Omid Sadeghipour and Parviz Aghaei(2012). Response of Common bean (Phaseolus vulgaris L.)to Exogenous Application of Salicylic Acid (SA) under Water Stress Conditions, Environmental Biology, 6(3): 11601168.

Pannu, R.K.; and D.P.Singh(1988). Influence of water deficit on morophysiogical and yield behavior of mungbean (Vignaradiatal L.) mungbean. Proceedings of the second interactional symposium. Asian Vegetable Research and Development Center.AVRDC. pp. 252-259. 
Peterson, A.C (1989). Effect of water stress on phaseolus vulgaris $L$. and Phaseolus acutifolius var. Latifolius. Horticultural Abst. 59(4):333.

Santos, M.G. R.;V. Ribeiro, E.C. Machado and C. Pimentel (2009). Photosynthetic parameters and leaf water potential of five common bean genotypes under mild water deficit BIOLOGIA PLANTARUM 53 (2): $229-236$

Shen X.Y ad Webster D.B (1986). Effect of water stress on pollen of Phaseolus vulgaris L. J. Am. Soc. Hort. Sci. 111: 807-810.

Singer, y, L. H; A.N. Maras and A.F. Abou-hadid, (1996). Growth and development of bean plants (phaseolus vulgaris L.) Grown under water stress, Cahiers Options Méditerranéennevsovol .31, 241-250.

Singh, S.P(1995). Selection for water stress tolerance in interracial populations of common bean. Crop Sci. 35, 118-124.

Sponchiado, B.N.; J.W. White, J.A. Castillo, and P.G. Jones(1989). Root growth Of four common bean cultivars in relation to drought tolerance in environments with contrasting soil types. Exp. Agric. 25:249-257.

Szilagyi. L( 2003). Influence of drought on seed yield components In common bean, bulg. J. Plant physiol., special issue320-330.

Taiz, L. and E. Zeiger(2002) Plant Physiology, 3rd Edition. Senauer Assoc., Sunderland.MA. 690 pps.

Teran, H. and S.P. Singh ( 2002). Selection for drought resistance in early generations of common bean populations. Can. J. Plant Sci. 82:491497.

Thalooth ,A.T. M.;M. Tawfik and H. Magda Mohamed (2006).A comparative Study on the Effect of Foliar Application of Zinc, Potassium and Magnesium on Growth, Yield and Some Chemical Constituents of Mungbean Plants Grown under Water Stress Conditions, World Journal of Agricultural Sciences 2 (1): 37-46.

Ucar, A. K.; H. I. Yilmaz, G. I. Tuylu and N. Yardimci (2009). The effect of deficit irrigation on the grain yield of dry bean (Phaseolus vulgaris L.) in semiarid regions. Spanish Journal of Agricultural Research, 7(2), 474-485.

Verbruggen, $\mathrm{N}$ and C. Hermans (2008).Proline accumulation in plants: a review. Amino Acids 35: 753- 759.

Yancy, P.H,M.E.;Clark, S.C. Hand, R.D. Bowlus, G.N.Somero(1982). Living with water stress: evolution of osmolyte systems, Science 217: 12141223. 
النمـو الخضرى والمحصول وبعض الصفات الكيميائية للاوراق والقرونللفاصوليا

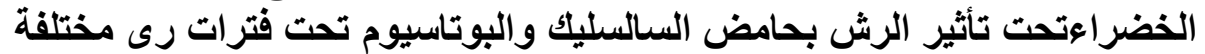

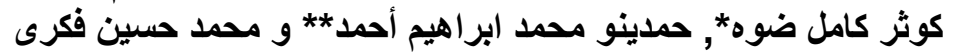

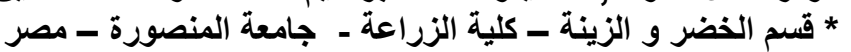

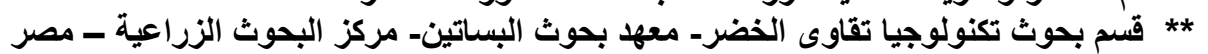

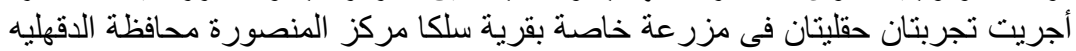

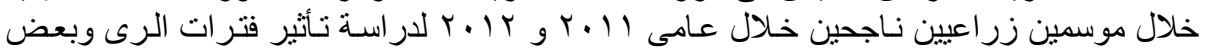

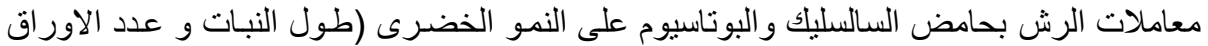

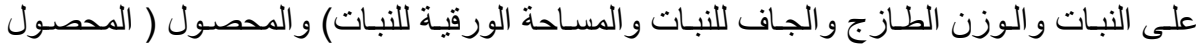

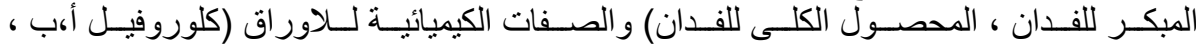

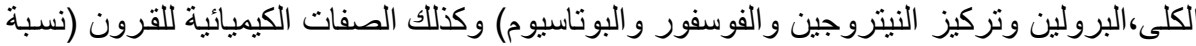

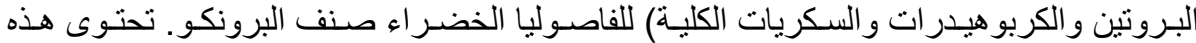

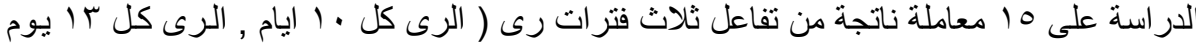

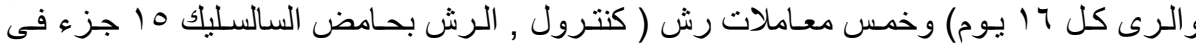

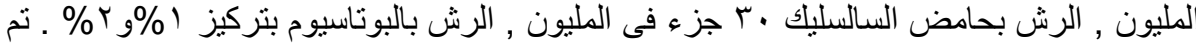

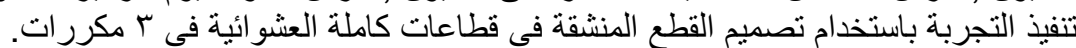

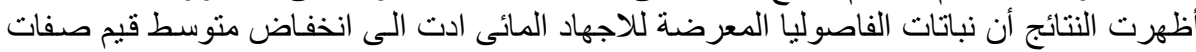

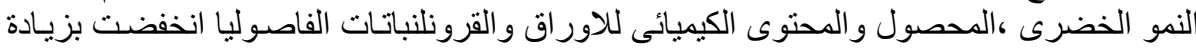

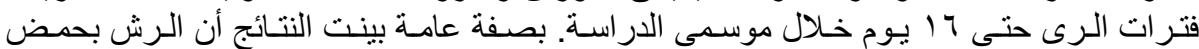

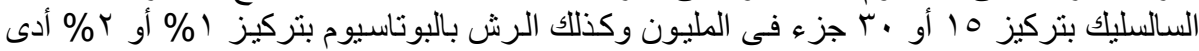

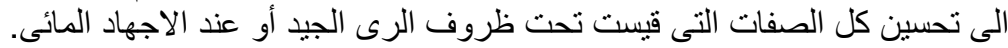

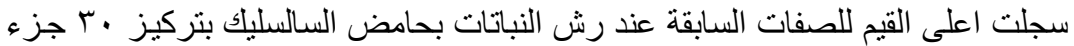

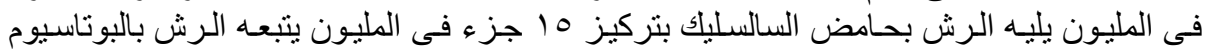

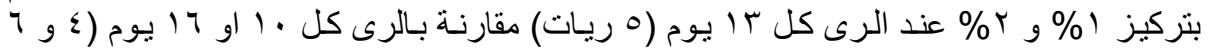

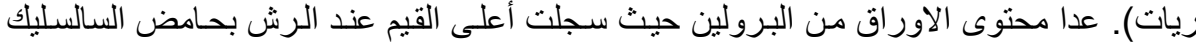

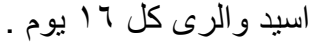
و هذه النتائج توضح دور كلا من حامض السالسليك و البوتاسيوم و الذيى يمكن استخدامه كمنظم نمو لتحسين نمو وانتاج نباتات الفاصوليا تحت ظروف الترف الاجهاد المائى. 
Table (2): vegetative growth characters of bean plants as affected by irrigation intervals, foliar treatments and their interactions during 2011 and 2012 seasons.

\begin{tabular}{|c|c|c|c|c|c|c|c|c|c|c|c|c|c|}
\hline \multirow{2}{*}{\multicolumn{2}{|c|}{ Characters }} & \multicolumn{2}{|c|}{$\begin{array}{l}\text { Plant height } \\
\text { (cm) }\end{array}$} & \multicolumn{2}{|c|}{ No. of leaves/plant } & \multicolumn{3}{|c|}{$\begin{array}{c}\text { fresh weight } \\
\text { g/plant }\end{array}$} & \multicolumn{3}{|c|}{$\begin{array}{l}\text { Foliage dry weight } \\
\text { g/ plant }\end{array}$} & \multicolumn{2}{|c|}{$\begin{array}{l}\text { Leaf area/plant } \\
(\mathrm{cm})^{2}\end{array}$} \\
\hline & & 2011 & 2012 & 2011 & 2011 & 2011 & & 2012 & 2011 & & 2012 & 2011 & 2012 \\
\hline \multicolumn{14}{|c|}{ Irrigation intervals } \\
\hline \multirow{2}{*}{\multicolumn{2}{|c|}{\begin{tabular}{|l|}
10 days \\
13 days
\end{tabular}}} & $41.77 \mathrm{~b}$ & $45.13 \mathrm{~b}$ & $10.66 \mathrm{~b}$ & $12.06 \mathrm{~b}$ & 70.40 & $\mathrm{~b}$ & $64.40 \mathrm{~b}$ & $7.94 k$ & & $10.86 k$ & 1043.92 & $967.26 \mathrm{~b}$ \\
\hline & & $42.37 \mathrm{a}$ & $47.40 \mathrm{a}$ & $11.20 \mathrm{a}$ & $12.86 \mathrm{a}$ & 71.49 & $a$ & 73.26 a & 8.66 & $a$ & 12.06 & 1030.84 & $1064.95 a$ \\
\hline \multicolumn{2}{|l|}{16 days } & $36.28 \mathrm{c}$ & $41.90 \mathrm{c}$ & $10.00 \mathrm{c}$ & $11.13 \mathrm{c}$ & 62.36 & $\mathrm{c}$ & $58.67 \mathrm{c}$ & 6.43 & $\mathrm{c}$ & 9.27 & 797.11 & $825.1 \quad \mathrm{c}$ \\
\hline \multicolumn{14}{|c|}{ Foliar treatments } \\
\hline \multirow{2}{*}{\multicolumn{2}{|c|}{ Control }} & $36.80 \mathrm{e}$ & $40.83 \mathrm{~d}$ & $9.77 \mathrm{e}$ & $10.66 \mathrm{~d}$ & 61.54 & $\mathrm{e}$ & 57.46 & 6.92 & & 9.72 & 878.12 & $858.71 \mathrm{c}$ \\
\hline & & $41.45 \mathrm{~b}$ & $46.40 a b$ & $11.00 \mathrm{~b}$ & $12.55 \mathrm{~b}$ & 70.29 & $\mathrm{~b}$ & 68.26 & $7.98 k$ & $\mathrm{~b}$ & 11.06 & 980.80 & $970.24 a b$ \\
\hline \multicolumn{2}{|c|}{ SA $30 \mathrm{ppm}$} & $43.12 \mathrm{a}$ & $46.90 \mathrm{a}$ & $11.33 \mathrm{a}$ & $13.44 \mathrm{a}$ & 72.74 & $a$ & 70.98 & 8.22 & $a$ & 11.73 & 989.83 & $999.54 \mathrm{a}$ \\
\hline \multicolumn{2}{|c|}{ K 1\% } & $40.04 \mathrm{c}$ & $45.76 \mathrm{~b}$ & $10.66 \mathrm{c}$ & $11.88 \mathrm{c}$ & 68.82 & c & 65.97 & 7.74 & c & 10.73 & 975.52 & $971.80 \mathrm{ab}$ \\
\hline \multicolumn{2}{|l|}{$\mathrm{K} 2 \%$} & $39.29 \mathrm{~d}$ & $44.15 \mathrm{c}$ & $10.33 \mathrm{~d}$ & $11.55 \mathrm{c}$ & 67.03 & $d$ & 64.54 & 7.52 & $d$ & $10.41 \mathrm{c}$ & 962.190 & $961.97 \mathrm{~b}$ \\
\hline \multicolumn{14}{|c|}{ Interaction } \\
\hline \multirow{5}{*}{10 days } & Control & $39.34 \mathrm{~d}$ & $42.40 \mathrm{f}$ & $10.33 \mathrm{c}$ & 11.33def & 67.50 & $\mathrm{e}$ & 58.60 & 7.11 & $f$ & 10.13 & 1004.02 & $928.20 \mathrm{~cd}$ \\
\hline & SA $15 \mathrm{ppm}$ & $42.56 \mathrm{~b}$ & $46.00 \mathrm{~cd}$ & $11.00 \mathrm{~b}$ & $12.33 \mathrm{bcd}$ & 71.09 & $\mathrm{c}$ & 66.26 & 8.23 & & 11.11 & 1061.83 & $982.50 \mathrm{~b}$ \\
\hline & SA $30 \mathrm{ppm}$ & $44.29 \mathrm{a}$ & $46.20 \mathrm{~cd}$ & $11.00 \mathrm{~b}$ & $13.33 \mathrm{ab}$ & 73.39 & $\mathrm{~b}$ & 69.76 & 8.50 & & 11.43 & 1063.51 & $985.25 \mathrm{~b}$ \\
\hline & K 1\% & $41.40 \mathrm{bc}$ & $45.63 \mathrm{~cd}$ & $11.00 \mathrm{~b}$ & $11.66 \mathrm{cdf}$ & $70.29 \mathrm{c}$ & & 64.53 ef & 8.17 & $d$ & 11.05 & 1061.97 & 978.43 bc \\
\hline & K 2\% & $41.24 \mathrm{C}$ & $45.43 \mathrm{~d}$ & $10.00 \mathrm{~d}$ & $11.66 \mathrm{cdf}$ & 69.72 & $\mathrm{~d}$ & $62.86 \mathrm{f}$ & $7.71 \epsilon$ & $\mathrm{e}$ & 10.62 & 1028.27 & $961.95 \mathrm{bc}$ \\
\hline \multirow{5}{*}{13 days } & Control & $38.58 \mathrm{de}$ & $41.96 \mathrm{f}$ & $10.00 \mathrm{~d}$ & 11.00 ef & 62.28 & $g$ & 58.26 & 7.62 & $\mathrm{e}$ & 10.34 & 868.90 & $894.23 \mathrm{~d}$ \\
\hline & SA $15 \mathrm{ppm}$ & $44.40 \mathrm{a}$ & $49.60 \mathrm{a}$ & $12.00 \mathrm{a}$ & $13.33 \mathrm{ab}$ & 73.67 & $\frac{g}{b}$ & 78.46 & 9.19 & $a$ & 12.65 & 1068.57 & $1112.05 \mathrm{a}$ \\
\hline & SA $30 \mathrm{ppm}$ & $45.34 \mathrm{a}$ & $49.90 \mathrm{a}$ & $12.00 \mathrm{a}$ & $14.33 \mathrm{a}$ & 77.42 & $a$ & 81.33 & 9.26 & $a$ & 13.82 & 1081.87 & $1122.77 \mathrm{a}$ \\
\hline & K 1\% & $42.29 b c$ & $48.40 \mathrm{ab}$ & $11.00 \mathrm{~b}$ & $13.33 \mathrm{ab}$ & 73.11 & $\mathrm{~b}$ & 74.86 & $8.67 \mathrm{k}$ & & 11.92 & $1068.05 b$ & $1104.12 \mathrm{a}$ \\
\hline & K 2\% & $41.26 \mathrm{c}$ & $47.13 b c$ & $11.00 \mathrm{~b}$ & $12.33 \mathrm{bcd}$ & 70.98 & c & 73.40 & 8.55 & c & $11.56 \mathrm{c}$ & 1066.81 & $1091.59 a$ \\
\hline \multirow{5}{*}{16 days } & Control & $32.48 \mathrm{~h}$ & $38.13 \mathrm{~h}$ & $9.00 \mathrm{e}$ & $9.66 \mathrm{~g}$ & 54.8 & i & 55.53 & 6.05 & & $8.70 \mathrm{n}$ & $761.44 \mathrm{n}$ & $753.72 f$ \\
\hline & SA $15 \mathrm{ppm}$ & 37.40 ef & 43.60 ef & $10.00 \mathrm{~d}$ & $12.00 \mathrm{cde}$ & 66.11 & $f$ & $60.06 \mathrm{gh}$ & 6.50 & $\mathrm{~h}$ & 9.42 & 811.99 & $816.18 \mathrm{e}$ \\
\hline & SA $30 \mathrm{ppm}$ & $39.73 \mathrm{~d}$ & $44.60 \mathrm{de}$ & $11.00 \mathrm{~b}$ & $12.66 \mathrm{bc}$ & 67.41 & e & $\begin{array}{ll}61.86 \mathrm{fg} \\
\end{array}$ & 6.91 & $g$ & 9.96 & 824.10 & $890.60 \mathrm{~d}$ \\
\hline & $\mathrm{K} 1 \%$ & $36.58 f$ & 43.26 ef & $10.00 \mathrm{~d}$ & $10.66 \mathrm{fg}$ & 63.05 & $\mathrm{~g}$ & $58.53 \mathrm{~h}$ & 6.37 & & 9.23 & 796.55 & $832.86 \mathrm{e}$ \\
\hline & K 2\% & $35.21 \mathrm{~g}$ & $39.90 \mathrm{~g}$ & $10.00 \mathrm{~d}$ & $10.66 \mathrm{fg}$ & 60.39 & $\frac{y}{h}$ & $57.36 \mathrm{hi}$ & 6.31 & i & 9.05 & 791.50 & $832.36 \mathrm{e}$ \\
\hline
\end{tabular}

Values within the same column followed by the same letters are not significantly different using Duncan's Multiple Range Test at $5 \%$ level. 